\title{
Effect of roofing materials on micro-climate in loose house for animals during rainy season
}

\author{
Reena Kamal, Triveni Dutt, B. H. M. Patel, R. P. Ram ${ }^{1}$, Probhakar Biswas, P. K. Bharti and Sandeep Kaswan \\ Indian Veterinary Research Institute, Izatnagar -243 122, Dist. Bareilly (UP) India; \\ 1. Veterinary Officer, Palamau, Jharkhand, India \\ Corresponding author: Probhakar Biswas, email:probhakarvet@gmail.com \\ Received: 11-12-2012, Revised: 17-01-2013, Accepted: 19-01-2013, Published online: 11-05-2013
}

\section{How to cite this article:}

Kamal R, Dutt T, Patel BHM, Ram RP, Biswas P, Bharti PK and Kaswan S (2013) Effect of roofing materials on micro-climate in loose house for animals during rainy season, Vet World 6(8): 482-485, doi:10.5455/vetworld.2013.482-485

\begin{abstract}
Aim: To find out the influence of different types of roofing materials on micro-climate in animal loose housing system during rainy season.

Materials and Methods: Different shade materials were used for covered area under each of three treatments. Thatch shading roof $\left(\mathrm{T}_{1}\right)$, Agro-net shading roof $\left(\mathrm{T}_{2}\right)$, Asbestos with canvas shading roof $\left(\mathrm{T}_{3}\right)$. Long axis of the paddock was east-to-west orientation. The covered area floor space was $1.5 \times 1 \mathrm{~m}$ (excluding manger) for each animal and open paddock was $2 \times 1 \mathrm{~m}$. Height of shed at eaves was 2 meter. Daily temperature (maximum and minimum) and dry bulb and wet bulb temperature of macro and micro- environment under different treatments were recorded at 9:30 AM and 2:00 PM of Indian Standard Time (IST) by using maximum and minimum thermometer and dry and wet bulb thermometer. Both inside and outside surface temperatures of shade materials were measured by infrared digital thermometer (ebro, TFI 220). The statistical procedures followed were two way ANOVA and Paired 'T' test.

Results: During the experimental period, maximum temperature was recorded under asbestos and lowest temperature was in agro-net and maximum protection from high temperature was given during peak hot hours in agro-net than asbestos. THI was more $(P<0.05)$ under asbestos than agro-net and thatch. The outside surface temperature at 9.30 AM and 2:00 PM (IST) was significantly lower $(P<0.05)$ in agro-net than thatch and asbestos.
\end{abstract}

Conclusion: Thatch and agro-net were better in warding off the hot and humid environmental condition in comparison to asbestos.

Keywords: agro-net, asbestos, micro-climate, shade, temperature humidity index, thatch

\section{Introduction}

Basic concept of housing is that it should normally buffer the extremes of climatic condition to lower peak stress on animal and provide protection from predators. It should also create a microenvironment inside the animal house, which protects the animal from stressful environment and allow efficiency of labor utilization. Global warming and climate change may be a threat to livestock production in many regions of the world [1]. In India the extreme temperature often leads to lots of problem in animal rearing. One of the most important purpose of livestock shed is to reduce the heat load on animals sheltered under it. Proper shade reduces the severity of the heat stress compared to open sky [2]. The radiation that causes the heat load is often a sum or individual effect of direct radiation from the sun, the sky and the ground and a shade reduces the amount of radiation from each source [3]. The amount of reduction in radiant heat load and micro environment inside the shed depends on the design and the material used for the shade [4,5].

Different types of materials are used to provide

This article is an open access article licensed under the terms of the Creative Commons Attribution License (http://creativecommons. org/licenses/by/2.0) which permits unrestricted use, distribution and reproduction in any medium, provided the work is properly cited. shade to the animals and these ranges from solid materials like iron and asbestos sheets to shade cloths, which reduce solar radiation on the sheltered animal by different proportions [6] and protect the animals from rain or inclement weather. The quality of shade material to a great extent decide the micro-climate of animal houses and should ideally be light, strong, durable, weatherproof, good looking, bad conductor of heat and free from tendency to condense moisture inside. Macro and micro-climate has profound effect on physiological response and growth of calf based on the degree of comfort [7]. Covering the roof with a thatching materials proved beneficial and resulted significantly $(P<0.01)$ higher body weight gains over to tin roofing [8] in Osmanabadi kids. Greenhouse barns provide a healthy environment for calves, heifers and cows [9]. There is beneficial effect of shade cloth on animal performance by minimizing the heat stress [10]. Rainy season in northern India is often coupled with high environmental temperature and high relative humidity, leading to uncomfortable Temperature humidity index (THI).

Taking into consideration the above mentioned situations, the present study was carried out to find out the influence of different types of roofing materials on micro-climate in animal loose housing system in rainy season. 
Table-1. Minimum and maximum temperature of micro-climate (under different shade materials) and macro-climate during rainy season

\begin{tabular}{|c|c|c|c|c|c|c|c|c|}
\hline \multirow[t]{3}{*}{ Month } & \multicolumn{6}{|c|}{ Micro-climate } & \multicolumn{2}{|c|}{ Macro-climate } \\
\hline & \multicolumn{2}{|c|}{ Thatch } & \multicolumn{2}{|c|}{ Agro-net } & \multicolumn{2}{|c|}{ Asbestos } & \multirow[b]{2}{*}{$\operatorname{Min} .\left({ }^{\circ} \mathrm{C}\right)$} & \multirow[b]{2}{*}{$\operatorname{Max} .\left({ }^{\circ} \mathrm{C}\right)$} \\
\hline & $\operatorname{Min} .\left({ }^{\circ} \mathrm{C}\right)$ & $\operatorname{Max} .\left({ }^{\circ} \mathrm{C}\right)$ & $\operatorname{Min} .\left({ }^{\circ} \mathrm{C}\right)$ & $\operatorname{Max} .\left({ }^{\circ} \mathrm{C}\right)$ & Min. $\left({ }^{\circ} \mathrm{C}\right)$ & $\operatorname{Max} .\left({ }^{\circ} \mathrm{C}\right)$ & & \\
\hline I & $26.52 \pm 0.32^{c}$ & $32.40 \pm 0.93^{\mathrm{A}}$ & $22.80 \pm 0.40^{a}$ & $32.72 \pm 0.79^{A}$ & $24.43 \pm 0.41^{b}$ & $33.91 \pm 0.91^{\mathrm{A}}$ & $28.57 \pm 0.64^{d}$ & $38.27 \pm 0.96^{\mathrm{B}}$ \\
\hline II & $24.71 \pm 0.25^{c}$ & $31.55 \pm 0.39^{A}$ & $21.45 \pm 0.27^{a}$ & $31.90 \pm 0.38^{A B}$ & $23.74 \pm 0.26^{b}$ & $33.0 \pm 0.45^{\mathrm{B}}$ & $26.74 \pm 0.31^{d}$ & $35.71 \pm 0.52^{C}$ \\
\hline III & $25.58 \pm 0.31^{b}$ & $31.12 \pm 0.36^{\mathrm{A}}$ & $21.0 \pm 0.29^{a}$ & $31.77 \pm 0.49^{A}$ & $23.41 \pm 0.30^{b}$ & $33.67 \pm 0.48^{B}$ & $26.29 \pm 0.26^{c}$ & $35.22 \pm 0.47^{c}$ \\
\hline Overall & $24.82 \pm 0.21^{c}$ & $31.64 \pm 0.32^{A}$ & $21.67 \pm 0.19^{a}$ & $32.09 \pm 0.31^{\mathrm{A}}$ & $23.81 \pm 0.18^{b}$ & $33.48 \pm 0.34^{\mathrm{B}}$ & $27.17 \pm 0.25^{d}$ & $36.34 \pm 0.40^{C}$ \\
\hline
\end{tabular}

Mean bearing different superscript $(a, b, c)$ differ significantly $(P<0.05)$ at 9:30 AM and $(A, B, C)$ differ significantly $(P<0.05)$ at 2:00 PM of IST.

\section{Materials and Methods}

Ethical approval: The experiment followed the guidelines of Institutional Animal Ethics Committee.

The present study (part of a larger study) was conducted at the Cattle and Buffalo Farm, Indian Veterinary Research Institute, Izatnagar. Six crossbred calves (3days to 3 months of age) were housed under each treatment. Different shade materials were used for covered area under each treatment in following manner. $T_{1}$ : Thatch shading roof: Layer of paddy straw of 4 inch thickness was fixed to bamboo frame, $\mathrm{T}_{2}$. Agro-net shading roof (green and black colored woven threads which provided $60 \%$ light diffusion), $\mathrm{T}_{3}-$ Asbestos with canvas shaded roof: commercially available asbestos was used and canvas laid over outer surface with 2-3 inch gap between them to reduce the thermal conductivity of asbestos. Long axis of the paddock had East-West orientation with brick on edge floor. The covered area floor space was $1.5 \times 1 \mathrm{~m}$ (excluding manger) for each animal and open paddock was $2 \times 1 \mathrm{~m}$. Height of shed at eaves was 2 meters. The thermal conductivity of thatch and asbestos were 0.05 and $0.40 \mathrm{Kcal} / \mathrm{mtr},{ }^{\circ} \mathrm{C}$ [11]. The study was undertaken both in summer and rainy seasons. But as in northern part of India the temperature and humidity at the rainy season remains high resulting in high THI which is the main concern of the paper and research, so only the data pertaining to the rainy season has been analyzed and provided. Data from $16^{\text {th }}$ June to $15^{\text {th }}$ September, 2012 has analyzed and provided here.

Daily temperature (maximum and minimum) and dry bulb and wet bulb temperature of macro and microenvironment under different treatments were recorded at 9:30 AM and 2:00 PM of Indian Standard Time (IST) by using maximum and minimum thermometer and dry and wet bulb thermometer. The instruments were hanged at equal heights by thread in covered area under each treatment roof and at equal height in the open area for macro-environmental records. THI at aforesaid time was calculated as per [12] using the following formula.

$\mathrm{THI}=0.72$ (wet bulb temperature + dry bulb temperature) $+40.6$

Both inside and outside surface temperature of shade materials were measured by infrared digital thermometer, keeping it 2-3 inch away from the desired surface.
Statistical analysis: The statistical procedures followed were two way ANOVA and paired 'T' test.

\section{Results and Discussion}

The macro, maximum and minimum ambient temperature and THI during the experimental period have been presented in Table-1. The minimum and maximum temperatures were $27.17 \pm .0 .25$ and $36.34 \pm$ 0.40 whereas the maximum THI was calculated to be $82.82 \pm 0.25$ and $85.96 \pm 0.41$ at 9:30 AM and 2:00 PM, respectively, which clearly indicated that the ambient environmental temperature were stressful during the experimental period.

Minimum and maximum temperature recorded under shed of different shade material has been presented in table 1. Among all the shades, minimum temperature $(P<0.05)$ was recorded in agro-net followed by asbestos and thatch. The findings are in line with [13] who reported lowest minimum temperature in asbestos than thatch and literoof. Higher minimum temperature in August in loose housing system was reported by [14].

In the present study maximum temperature $(P<0.05)$ was recorded in asbestos shed followed by agro-net and thatch. The difference between maximum and minimum temperature was highest $\left(12.7+7.0^{\circ} \mathrm{C}\right)$ in the asbestos-roofed houses (Min. and Max. $26.3^{\circ} \mathrm{C}$ and $\left.39^{\circ} \mathrm{C}\right)$ and the lowest $\left(2.7+2.0^{\circ} \mathrm{C}\right)$ in the coconut frond thatched houses (Min. and Max. $30.6^{\circ} \mathrm{C}$ and $33.3^{\circ} \mathrm{C}$ ) reported by [15]. The higher maximum temperature under asbestos could be attributed to ineffective loss of absorbed heat. The micro-environments at different heights under different roof material were studied and [13] concluded that during peak hot hours maximum protection was provided in thatch/improved thatch than asbestos. Shade protect from external environmental temperature by creating a suitable or better micro-environment within the animal house or shed. Thai Brahman heifers under artificial shed or tree shade were better protected that those without shade [16]. He also reported that artificial shed blocked sunlight better than trees.

Lowest dry bulb temperature in shelter having $\mathrm{RCC}$ roof as compared to asbestos roof shelters and conventional tree shelters was reported by [17]. Tile roof had lower maximum temperature as reported by [7].

THI of both micro (under different shades) and macro-climate has been presented in Table-2. At 9.30 AM and 2:00 PM (IST) the THI was found to be 
doi:10.5455/vetworld.2013.482-485

Table-2. THI values of micro-climate (under different shade materials) and macro-climate during rainy season

\begin{tabular}{|c|c|c|c|c|c|c|c|c|}
\hline \multirow[t]{3}{*}{ Month } & \multicolumn{6}{|c|}{ Micro-climate } & \multicolumn{2}{|c|}{ Macro-climate } \\
\hline & \multicolumn{2}{|c|}{ Thatch } & \multicolumn{2}{|c|}{ Agro-net } & \multicolumn{2}{|c|}{ Asbestos } & \multirow[b]{2}{*}{ 9:30 AM } & \multirow[b]{2}{*}{ 2:00PM } \\
\hline & 9:30AM & 2:00PM & 9:30 AM & 2:00 PM & $9: 30 \mathrm{AM}$ & 2:00 PM & & \\
\hline I & $76.2 \pm 0.79^{\mathrm{ab}}$ & $79.9 \pm 1.41^{\mathrm{A}}$ & $75.07 \pm 0.84^{a}$ & $80.46 \pm 1.1^{A}$ & $77.32 \pm 0.75^{b}$ & $82.16 \pm 1.12^{B}$ & $83.78 \pm .64^{c}$ & $87.64 \pm 1.0^{C}$ \\
\hline II & $76.0 \pm 0.45^{\mathrm{b}}$ & $78.77 \pm 0.52^{\mathrm{AB}}$ & $74.21 \pm 0.53^{a}$ & $77.55 \pm 0.61^{\mathrm{A}}$ & $76.63 \pm 0.40^{\mathrm{b}}$ & $79.20 \pm 0.55^{B}$ & $82.60 \pm .3^{c}$ & $85.43 \pm 0.54^{\mathrm{C}}$ \\
\hline III & $76.7 \pm 0.44^{\mathrm{ab}}$ & $78.9 \pm .50^{A}$ & $75.53 \pm 0.52^{a}$ & $78.55 \pm 0.66^{A}$ & $77.17 \pm 0.43^{\mathrm{b}}$ & $79.73 \pm 0.54^{A}$ & $82.26 \pm .36^{\mathrm{c}}$ & $85.14 \pm 0.50^{\mathrm{B}}$ \\
\hline Overall & $76.30 \pm 0.32^{b}$ & $79.13 \pm 0.47^{\mathrm{AB}}$ & $74.92 \pm 0.36^{a}$ & $78.74 \pm 0.46^{A}$ & $77.01 \pm 0.29^{b}$ & $80.24 \pm 0.44^{B}$ & $82.82 \pm 0.25^{c}$ & $85.96 \pm 0.41^{\mathrm{C}}$ \\
\hline
\end{tabular}

Mean bearing different superscript $(a, b, c)$ differ significantly $(P<0.05)$ at 9:30 AM and $(A, B, C)$ differ significantly $(P<0.05)$ at $2: 00$ PM of IST

Table-3. Surface temperature $\left({ }^{\circ} \mathrm{C}\right)$ of different shade materials during rainy season

\begin{tabular}{|c|c|c|c|c|c|}
\hline Month & Surface & Time & Thatch & Agro-net & Asbestos \\
\hline \multirow[t]{4}{*}{ I } & \multirow[t]{2}{*}{ Roof outside } & 9:30 AM & $61.90 \pm 8.78^{b}$ & $34.08 \pm 2.70^{a}$ & $50.56 \pm 6.08^{\mathrm{ab}}$ \\
\hline & & 2:00 PM & $59.56 \pm 8.40^{b}$ & $33.62 \pm 2.70^{a}$ & $52.22 \pm 5.73^{\mathrm{ab}}$ \\
\hline & \multirow[t]{2}{*}{ Roof inside } & $9: 30$ AM & $32.62 \pm 3.25^{\mathrm{ab}}$ & $25.28 \pm 0.91^{a}$ & $37.54 \pm 5.03^{b}$ \\
\hline & & 2:00 PM & $34.94 \pm 6.44^{\mathrm{ab}}$ & $26.86 \pm 1.25^{a}$ & $44.84 \pm 4.44^{\mathrm{b}}$ \\
\hline \multirow[t]{4}{*}{ II } & \multirow[t]{2}{*}{ Roof outside } & $9: 30$ AM & $55.42 \pm 7.5^{\mathrm{b}}$ & $31.42 \pm 1.74^{a}$ & $52.32 \pm 5.54^{b}$ \\
\hline & & 2:00 PM & $56.16 \pm 6.84^{b}$ & $32.02 \pm 2.34^{a}$ & $49.90 \pm 6.2^{b}$ \\
\hline & \multirow[t]{2}{*}{ Roof inside } & 9:30 AM & $27.94 \pm 1.27^{a}$ & $26.08 \pm 1.14^{a}$ & $37.56 \pm 4.60^{b}$ \\
\hline & & 2:00 PM & $31.08 \pm 1.90^{\mathrm{a}}$ & $24.74 \pm 1.3^{a}$ & $41.08 \pm 4.70^{b}$ \\
\hline \multirow[t]{4}{*}{ III } & \multirow[t]{2}{*}{ Roof outside } & $9: 30$ AM & $52.65 \pm 1.55^{\mathrm{b}}$ & $35.85 \pm 0.85^{a}$ & $60.95 \pm 0.95^{c}$ \\
\hline & & 2:00 PM & $55.15 \pm 1.25^{\mathrm{b}}$ & $36.80 \pm 0.4^{a}$ & $65.70 \pm 0.70^{c}$ \\
\hline & \multirow[t]{2}{*}{ Roof inside } & 9:30 AM & $32.25 \pm 0.55^{\mathrm{b}}$ & $25.70 \pm 0.70^{\mathrm{a}}$ & $50.85 \pm 0.85^{c}$ \\
\hline & & 2:00 PM & $34.45 \pm 1.65^{\mathrm{b}}$ & $24.05 \pm 1.25^{a}$ & $50.40 \pm 10^{c}$ \\
\hline \multirow[t]{4}{*}{ Overall } & \multirow[t]{2}{*}{ Roof outside } & 9:30 AM & $57.65 \pm 4.65^{\mathrm{b}}$ & $33.26 \pm 1.36^{a}$ & $53.02 \pm 3.38^{b}$ \\
\hline & & 2:00 PM & $57.40 \pm 7.69^{b}$ & $33.48 \pm 1.48^{\mathrm{a}}$ & $53.50 \pm 3.70^{b}$ \\
\hline & \multirow[t]{2}{*}{ Roof inside } & $9: 30$ AM & $30.60 \pm 1.52$ & $25.68 \pm 0.58$ & $39.76 \pm 3.0$ \\
\hline & & 2:00 PM & $33.25 \pm 1.68^{b}$ & $25.50 \pm 0.80^{a}$ & $44.20 \pm 2.78^{c}$ \\
\hline
\end{tabular}

Mean bearing different superscript differ significantly $(P<0.05)$ row wise

significantly $(P<0.05)$ lower for agro-net as compared to asbestos and thatch. Wooden shade structure did not influence the THI in winter [18]. Mean THI values were significantly $(P<0.01)$ different between sheds (thatch, literoof/ asphalt cardboard corrugated sheets and asbestos) and between months [13]. The values were significantly higher (>75) in literoof shed (April to September) in comparison to those in thatch and asbestos. On the other hand [19\& 20] reported that THI beneath the shade cloth (blocking $80 \%$ of ambient solar radiation) was similar to THI outside the shade.

Surface (outside and inside) temperature of different shade material has been presented in Table- 3 . The outside surface temperature at 9.30 AM (IST) were significantly lower $(P<0.05)$ for agro-net than thatch and asbestos. Similar pattern were also observed for outside surface temperature at 2:00 PM (IST). At 2.00 PM surface temperature of agro-net was significantly lower $(P<0.05)$ followed by thatch and asbestos. The surface temperature data clearly indicated that the agro-net was better to reduce the solar radiation compared to other shade materials. Which differs from the findings of [21] who concluded that inside and outside surface of hutch in both shaded and un-shaded area did not differed significantly.

\section{Conclusion}

Due to high thermal conductivity asbestos could not protect the animal in afternoon compared to forenoon. Thatch and agro-net were able to reduce the negative effect of environmental variables and can prove to be effective in warding off the hot and humid environmental condition than asbestos. The findings of the present study show scope for further research on the influence of the used roofing materials on behavior, stress level, reproduction and production of animals. Further investigation regarding the economics and durability of the mentioned materials can be carried out.

\section{Authors' contribution}

All authors are contributed equally. All authors read and approved the final manuscript.

\section{Acknowledgements}

The authors are thankful to the Director and Joint Director (Academic) of IVRI, Izatnagar for providing necessary funds and facilities to carry out research.

\section{Competing interests}

Authors declare that they have no competing interest.

\section{References}

1. Gaughan, J.B., Mader, T.L., Holt, S.M., Sullivan, M.1. and Hahn, G.L. (2009) Assessing the heat tolerance of 17 beef cattle genotypes. Int. J. Biometeorol., 54: 617-627. doi: 10.1007/s00484-009-0233-4.

2. Singh, D.N, Wadhmani, K.S., Arya, J.S., Sarvaiya, N.P. and Patel, A.M. (2008) Effect of blood constitute of ewes during summer in a subtropical climate. J. of Small Rumi., 14(1):252-254

3. Thomas, C.K. and Sastry, N.S.R. (2007) Problems of Dairy production in Hot Regions. Dairy Bovine Production. $1^{\text {st }}$ edition, Kalyani Publisher, Ludhiana, pp : 111.

4. Adam, S. (2006) Heat stress and the SNF: Fat ratio. Don't let scoring heat make your life difficult. Producteur de Lait 
Quebecosis 25(9): 19-20. Dairy Sci. Abst., 68(7):3378.

5. Badino, F. (2007) Helping cows to regulate body heat. Informative Agarino Supplemento., 62 (39):18-21.

6. Haque, N. and Hussain, S.A. (2011) Dairy Articles, www. poulvet.com/dairy/articles/dairy_housing_new.php. Retrived on 7th March, 2012.

7. Roy, P.K. and Chatterjee, A. (2010) Effect of different types of dairy cattle shelters on micro-climatic variables in rural West Bengal. Indian J. of Anim. Sci., 80(8):781-784.

8. Patil, R.A., Karanjkar, L.M., Jadhav, V.S. and Narwade, S.G. (2008) Response in growth of Osmanabadi weaned kids to various housing patterns. Indian J. Anim. Res., 42 (1):2933

9. http:/www.Oenmsen,com/-Green house barns for dairy housing, Retrieved on 8th March, 2012.

10. Khongdee, S., Sripoon, S., Chousawai, S., Hinch, G., Chaiyabutr, N., Markvichitr, K. and Vajrabukka, C. (2010) The effect of modified roofing on the milk yield and reproductive performance of heat-stressed dairy cows under hot-humid conditions. Anim. Sci.J., 81 (5):606-611.

11. Sastry, N.S.R. and Thomas, C.K. (2008) Animal Housing. Livestock Production Management.Fourth edition, Kalyani Publisher, Ludhiana, pp :218.

12. Mc Dowell, R.E. (1972) Improvement of livestock production in warm climates. W.H. Freeman and Co., San Francisco, pp: 66-110.

13. Singh, K., Kumar, P., Saini, A.L. and Bhattacharyya, N.K. (1989) Micro-climate within three types of literoof sheds in hot semi-arid zone. Indian J. of Anim. Sci., 59 (8): 997-1005.
14. Sharma, P. and Singh, K. (2002) Effect of shelter system on environmental variables. Indian J. of Anim. Sci., 72(9):806809.

15. Vanitha, V. and Baskaran, N. (2009) Effect of Ambient temperature in different seasons and roofing materials on ear flapping by Asian Elephants in captivity. A study from Tamil Nadu, India. J. of Indian Vet. Assoc., 7(1): 22-27.

16. Aengwanich, W., Kongbuntad, W. and Boonsorn, T. (2011) Effects of shade on physiological changes, oxidative stress, and total antioxidant power in Thai Brahman Cattle. Int. J. Biometeorol., 55: 741-748. doi: 10.1007/s00484-010-0389-y.

17. Kaur, P and Singh, J. (2004) Effect of building design on thermal comfort inside different dairy shelters. Lives. Intern., 8(4):5-10.

18. Schütz, K. E., Rogers, A.R., Cox, N.R., and Tucker, C.B. (2009) Dairy cows prefer shade that offers greater protection against solar radiation in summer: Shade use, behaviour, and body temperature. Appl. Anim. Behav. Sci., 116:28-34.

19. Schütz, K.E., N.R. Cox. and Matthews, L.R. (2008) How important is shade to dairy cattle? Choice between shade or lying following different levels of lying deprivation. Appl. Anim. Behav. Sci., 114:307-318.

20. Tucker, C.B., Rogers, A.R. and Schütz, K.E., (2008) Effect of solar radiation on dairy cattle behaviour, use of shade and body temperature in a pasture-based system. Appl. Anim. Behav. Sci., 109:141-154.

21. Spain, J.N. and Spiers, D.E. (1996) Effects of supplemental shade on thermoregulatory response of calves to heat challenge in a hutch environment. J. Dairy. Sci., 79: 639-646.

\section{$* * * * * * * *$}

